\title{
COMPARTILHAR COM O PRÓXIMO
}

\author{
TSIPIBU ${ }^{1}$, Francisco Rodrigues Tserene'ewe \\ Universidade Federal de Goiás
}

\section{RESUMO}

Meu interesse maior é levantar a importância de conhecimento e comportamento para compartilhar com o próximo o nosso costume $A$ 'uwẽ Uptabi.

Palavras-chave: Compartilhamento. Costume milenar. Povo A'uwẽ.

\section{ABSTRACT}

My greatest interest is to raise the importance of knowledge and behavior to share with others in our custom A'uwe Uptabi.

Key words: Sharing. Millenarian custom. A’uwẽ people.

No povo Xavante existem hábitos de se dar as coisas, sem necessidade de devolver, o que se deu, algo para alguém ou próximo, um costume maravilhoso dos nossos ancestrais A'uwẽ Uptabi. Costume de se dar de graça ou até mesmo trocar por alguma coisa que interessa para a pessoa A'uwẽ Uptabi. Os compartilhamentos eram, ou são ainda, as caças, os frutos, as pescas e as batatas nativas. Um comportamento de consideração e compartilhamento de costume.

Além disso, tem muito mais a considerar. Ambos os clãs são muito importantes na organização social do povo A'uwẽ Uptabi, quaisquer que sejam. Ambos os clãs têm consideração de respeito um com o outro: PO'RE DZA'ÕNÕ X OWAWẼ.

Nas caças ou pescarias, ambos os clãs oferecem as trocas, como, também, aquele que teve péssima caça ganha de graça. É dado. Também os compartilhamentos acontecem com os artesanatos ou materiais para artesanatos. Isso é costume A'uwẽ Uptabi. A aprendizagem vem do acompanhamento e a observação das crianças como: os pais, os parentes e a comunidade adulta. A partir da compreensão, do observatório, as crianças aprendem a lidar com o costume de trocar ou dar. Assim compreendem as identificações de clãs.

1 Rede UFG/UFT/UFMA. Professor de Educação Básica. 
$\mathrm{Na}$ natureza Xavante, os ensinamentos são familiares e comunitários culturais. Então esse costume se manteve ou mantém após o contato, ou seja, mesmo tendo tido interferência do costume dos brancos, na minha observação, esse sistema de compartilhamento se manteve no século XX. Isso porque, mesmo existindo as entradas de produtos industrializados alimentícios nas aldeias, não se cobravam das coisas dadas ao próximo. É um costume maravilhoso e milenar que não exclui o próximo, não individualiza. É costume da natureza e cultura.

Bom, estamos no século XXI. Do contato até os dias atuais contemporâneos, tenho percebido mudanças, devido à inclusão ideológica eurocêntrica capitalista, que cria as ideias individualistas. Há ainda o costume de partilhar algo ao próximo, mas a ideia é não gastar o que tem. Aquilo que tem é da família e, se derem o que tem, ficará faltando. Isso porque as coisas são compradas ou, também, às vezes, as caças, as pescas e as frutas não se dão de graça. Isso vai exigir o sistema monetário. Ou compra ou fica sem.

Então, percebo que há mudança intelectual no povo $A$ 'uwẽ Uptabi, em relação ao compartilhamento das coisas, de se dar de graça, sem exigências de querer de volta do que se deu. Isso acontece muito. Mas, como eu disse, não estão totalmente deixados de lado esses costumes. Entendo que as visões geradas criam impacto social sem que o percebamos, ou através de mau ensino incompreensivo, ou por aqueles que estudaram nas cidades, que vêm com a visão distorcida, que não entendem das epistemologias culturais Xavante. É harmonioso viver com aquilo que é positivo e igualitário, pois é assim o costume $A$ 'uwẽ Uptabi. Tem que repartir algo ou se dar igual, de acordo com as famílias e os clãs.

Lembrar também da importância de comportamento e considerações um com o outro e levar esse conhecimento em sala de aula para fortalecer as ideias para as novas gerações, para compreenderem a importância de compartilhar ao próximo. Para manter o costume é preciso levar o conhecimento às escolas, desfrutar a sabedoria com alunos, para perceberem como é importante e organizado o nosso costume cultural no Xavante.

Pode se perceber que existem ideias em famílias, o não usufruto ao próximo para que não falte o que tem. Isso é certo, mas, lembrando pelo menos, no nosso costume, de colaborar no mínimo com alguma coisa. Assim não deixa de compartilhar e manter o nosso costume. 
As minhas análises de conhecimentos partiram do próprio saber. Não fiz nenhuma pesquisa relacionada a esses conceitos. Até porque já nasci aprendendo, respeitando a norma de ambos os clãs: PO'REDZA ÕNÔ X OWAWẼ.

Isso é muito importante na organização social do povo $A$ 'uwẽ Uptabi, tentando especificar a compreensão comportamental do meu povo Xavante. Percebo que não é controlável e inseguro num mundo globalizado recheado de ideias e tecnologias novas incontroláveis. 
